\title{
Teknik Modeling Dalam Bimbingan Kelompok Untuk Mengatasi Grief Remaja Pasca Kematian Orangtua
}

\author{
Lolang Maria Masi ${ }^{\text {a, }}{ }^{*}$, Christmas Prasetia Ate ${ }^{\text {b, } 2}$ \\ ${ }^{a}$ STKIP Citra Bina Nusantara, Indonesia \\ ${ }^{1}$ lolangmasi@gmail.com*; ${ }^{2}$ chris.ate@gmail.com \\ *korespondensi penulis
}

\author{
Informasi artikel \\ Received : \\ August 26, 2018. \\ Revised : \\ September 08,2018. \\ Publish : \\ January 01, 2019. \\ Kata kunci: \\ Teknik modeling \\ Bimbingan kelompok \\ Grief
}

Keywords:

Modeling Technique,

Group Guidance,

Grief

\begin{abstract}
ABSTRAK
Perilaku grief merupakan respon emosional terhadap kehilangan seseorang melalui kematian merupakan penderitaan emosional yang kuat serta mendalam dan dapat diekspresikan dengan berbagai cara. Tujuan dari penelitian ini adalah untuk menghasilkan model bimbingan kelompok dengan teknik modeling yang efektif untuk mengurangi perilaku grief siswa. Desain penelitian ini menggunakan metode Educational research and development, dengan jumlah sampel sebanyak 10 siswa. Model bimbingan kelompok dengan teknik modeling adalah layanan bimbingan yang diberikan secara kelompok dengan mengaktifkan dinamika kelompok melalui model. Model yang digunakan adalah Live Model dan Symbolic Model. Hasil uji coba lapangan menunjukan tingkat perilaku grief siswa mengalami penurunan. Tingkat perilaku grief siswa sebelum bimbingan kelompok adalah $66,5 \%$ dan setelah bimbingan kelompok menurun menjadi 45,69\%. Terjadi penurunan sebesar 20,81\%. Penurunan tersebut terjadi pada semua aspek perilai grief. Ini berarti model layanan bimbingan kelompok dengan teknik modeling efektif untuk mengurangi perilaku grief siswa.
\end{abstract}

Copyright (C) 2019 (Lolang Maria Masi ${ }^{a, 1^{*}}$, Christmas Prasetia Ate $\left.{ }^{b, 2}\right)$ All Right Reserved

How to Cite: Lolang Maria Masi ${ }^{a}{ }^{1 *}$, Christmas Prasetia Ate ${ }^{\text {b, } 2}$ (2019). Teknik Modeling Dalam Bimbingan Kelompok Untuk Mengatasi Grief Remaja Pasca Kematian Orangtua. Jurnal Inspirasi Pendidikan, 9(1), 25-32.

This work is licensed under a Creative Commons Attribution-ShareAlike 4.0 International License. Allows readers to read, download, copy, distribute, print, search, or link to the full texts of its articles and allow readers to use them for any other lawful purpose. The journal hold the copyright. 
Jurnal Inspirasi Pendidikan, VOL.9, NO.1, Edisi Januari 2019

Teknik Modeling Dalam Bimbingan Kelompok Untuk Mengatasi Grief Remaja Pasca Kematian Orangtua Lolang Maria Masi ${ }^{\text {a }} 1^{*}$, Christmas Prasetia Ate ${ }^{\text {b, } 2}$

Hal: 25-32

\section{Pendahuluan}

Perasaan kehilangan merupakan proses yang bervariasi, terdapat kesedihan yang mendalam, keadaan merana, depresi, dan identitas yang berubah, keadaan kesehatan yang memburuk, kesepian, dan menarik diri dari pergaulan, itu juga akan terjadi perubahan dan kekacauan pada pola hidup dan kegiatan sehari-hari. Suatu peristiwa kematian diawali dengan bereavement, yaitu suatu kehilangan karena kematian seseorang yang dirasakan dekat dengan yang sedang berduka dan proses penyesuaian diri kepada kehilangan (Papalia, 2008). grief adalah respon emosional yang dialami pada fase awal berduka. Peristiwa kematian bagi remaja akan lebih buruk lagi jika peristiwa kematian secara tiba-tiba atau mendadak dan tak terpikirkan oleh mereka. Peristiwa kematian mendadak atau tidak diharapkan akan benarbenar mengejutkan bagi orang yang ditinggalkan, karena mereka tidak memiliki kesempatan untuk menyiapkan diri secara psikologis untuk menghadapi kehilangan karena kematian orang yang dekat dengan dirinya (Papalia, dkk 2008). Duka cita adalah kelumpuhan emosional, tidak percaya, kecemasan akan berpisah, putus asa, sedih, dan kesepian yang menyertai disaat kita kehilangan orang yang kita cintai (Santrock 2008).

Penulis menemui subjek berinisial EM dilapangan, yang mengalami grief setelah ibunya meninggal secara mendadak karena serangan jantung. Lima (5) tahun sebelumnya EM kehilangan ayahnya karena penyakit paru-paru. EM berubah semenjak kematian orangtuannya. Sebelum orangtua EM meninggal, EM merupakan anak yang ceria. Semua berubah ketika orangtuannya meninggal. EM sangat terpukul dan semenjak kejadian itu, EM menjadi anak yang pendiam dan lebih tertutup dengan orang baru. Ketika orang tuanya meninggal, dia merasa kehilangan dari bagian dirinya. EM merasa tidak utuh dalam segala sesuatu dan segala sesuatu tidak akan pernah sama lagi. Beberapa bulan setelah kepergian orantuanya, EM masih sering menangis, bayangan tentang orangtuanya masih sering muncul dan EM berharap bisa bertemu dengan kedua orantuanya. Peristiwa kematian ayah dan ibunya membuat dia trauma.

Sama halnya dengan masalah yang dihadapi subjek berinisial TK yang saat ini berusia 16 tahun. Masalah yang dihadapi oleh TK hampir sama dengan yang dihadapi oleh EM, keduanya kehilangan orangtua namun kehilangan yang dihadapi oleh TK sangat tragis. Ia merasa shock karena kehilangan kedua orangtua dalam waktu satu (1) hari. Awalnya TK kehilangan ayahnya pada siang hari karena serangan jantung. Namun karena stres kehilangan suami maka ibu TK pun memutuskan untuk mengakhiri hidupnya dengan meminum rair keras sehingga enam (6) jam setelah TK kehilangan ayah, dia pun kehilangan ibunya. Hal ini membuat TK merasa putus asa karena kehilangan orang-orang yang dia kasihi dalam jangka waktu satu hari. Akibatnya TK melampiaskan kesedihannya dengan melakukan hal-hal yang merugikan dirinya sendiri bahkan orang lain. Jika hal tersebut dibiarkan dalam jangka waktu yang lama, maka dapat mengakibatkan depresi pada EM dan TK. Hal ini sesuai dengan hasil penyebaran skala perlaku grief pada siswa kelas XI IPA yang berjumlah 40 orang diperoleh jumlah rata-rata perliaku grief sebagai berikut: $40 \%$ siswa dengan kategori perilaku grief tinggi, 32,33\% siswa dengan kategori sedang, 17,64\% siswa dengan kategori kurang, dan 10,14\% siswa dengan kategori rendah. Data tersebut menunjukan sebagian besar siswa yang mengalami kehilangan orang terdekatnya, tingkat perlakau griefnya berada dalam kategori tinggi.Guru Bimbingan dan Konseling yang sekaligus sebagai konselor sekolah, perlu memperhatikan masalah-masalah yang dihadapi para anak didiknya. Khususnya permasalahan mengenai grief. Salah satu teknik Bimbingan dan Konseling yang bisa di gunakan adalah bimbingan kelompok.

Bimbingan kelompok merupakan proses pemberian bantuan yang diberikan individu dalam situasi kelompok. Bimbingan kelompok ditujukan untuk mencegah timbulnya masalah pada siswa dan mengembangkan potensi siswa (Romlah 2006). Bimbingan Kelompok juga 
Jurnal Inspirasi Pendidikan, VOL.9, NO.1, Edisi Januari 2019

Teknik Modeling Dalam Bimbingan Kelompok Untuk Mengatasi Grief Remaja Pasca Kematian Orangtua Lolang Maria Masi ${ }^{\text {a, }}{ }^{*}$, Christmas Prasetia Ate ${ }^{\text {b, } 2}$

Hal: $25-32$

merupakan sarana untuk menunjang perkembangan optimal masing-masing siswa, yang diharapkan dapat mengambil manfaat dari pengalaman ini bagi dirinya sendiri (Winkel \& Hastuti 2010). Melalui teknik modeling siswa dapat belajar melalui observasi dimana tingkah laku dari seorang individu atau kelompok, sebagai model, berperan sebagai rangsangan bagi pikiran-pikiran, sikap-sikap atau tingkah laku sebagai bagian dari individu yang lain yang mengobservasi model yang ditampilkan sehingga kecakapan-kecakapan sosial tertentu bisa diperoleh dengan mengamati dan mencontoh tingkah laku model-model yang ada, juga reaksi-reaksi emosional yang terganggu yang dimiliki seseorang bisa dihapus dengan cara siswa mengamati orang lain yang mendekati obyek-obyek ataus situasi-situasi yang ditakuti tanpa mengalami akibat-akibat yang menakutkan dengan tindakan yang dilakukannya. Bimbingan kelompok anak dapat menerima banyak masukan dari anggota kelompok. Sehingga anak mendapat informasi-informasi dari anggota yang bisa dijadikan acuan anak untuk berubah menjadi yang lebih baik. Seperti dalam Bandura (1997) "Banyak orang yang tidak meyakini terhadap pengalaman keberhasilannya sebagai sumber informasi mengenai kemampuan yang dimilikinya, sehingga modeling dapat menjadi teknik untuk meningkatkan keyakinan diri yang dimiliki seseorang".

\section{Metode}

Penelitian ini menggunakan metode penelitan dan pengembangan. Langkah-langkah yang ditempuh dalam penelitian pengembangan meliputi : 1) persiapan pengembangan model 2) merancang model hipotetik, 3) uji kelayakan model, 4) perbaikan model hipotetik, 5) uji lapangan (uji empirik) model hipotetik, 6) hasil akhir produk. Teknik pengumpulan data dalam penelitian ini dilakukan dengan menggunakan: 1) angket kuisioner untuk memperoleh informasi mengenai grief pasca kematian orangtua; 2) wawancara untuk memperoleh informasi tentang proses pelaksanaan teknik modeling dalam bimbingan kelompok. Data yang dikumpulkan kemudian dianalisis secara terpadu, dianalisis secara kualitatif dan kuantitatif.

\section{Hasil dan pembahasan}

Layanan bimbingan kelompok sudah dilaksanakan di Sekolah Menengah Atas(SMA) Negeri Sekecamatan Oebobo akan tetapi kegiatan yang dilaksanakan pada setiap tahapnya belum sesuai dengan ketentuan formal pelaksanaan layanan bimbingan kelompok sehingga efektivitas layanan belum tercapai secara optimal. Tingkat perilaku grief siswa pasca kematian orang tua di SMA Negeri 3 Kupang kelas XI yang berjumlah 40 siswa, diperoleh jumlah rata-rata perilaku grief siswa sebagai berikut : $40 \%$ siswa dengan peilaku grief tinggi, $32,33 \%, \%$ siswa dengan peilaku grief sedang, 17,64\% siswa dengan peilaku grief kurang dan $10,14 \%$ siswa dengan peilaku grief rendah.Secara operasional proses pengembangan model layanan bimbingan kelompok dengan teknik modeling untuk mengurangi perilaku grief tersusun atas 8 komponen sebagai berikut : 1) Rasional, 2) Visi dan Misi, 3) Tujuan, 4) Isi Bimbingan Kelompok, 5) Dukungan sistem yang terdiri dari (a) pengembangan program, (b) pengembangan staf, (c) anggota kelompok, (d) penataan kebijakan, 6) Materi, Perlakuan dan Tenik, 7) Tahapan Pelaksanaan, 8) Evaluasi dan Tindak Lanjut.

Analisis proses dan hasil yang dicapai oleh anggota kelompok membuktikan bahwa layanan bimbingan kelompok dengan teknik modeling efektif untuk mengurangi perilaku grief siswa SMA Negeri Sekecamatan Oebobo. Indikator keberhasilan proses pelaksanaan layanan dapat dilihat dari peran konselor dan anggota kelompok pada setiap tahapan, baik tahap pembentukan, peralihan, kegiatan dan pengakhiran, pada setiap tahapan tersebut konselor berusaha menanamkan nilai-nilai positif dari life model maupun simbolic model sehingga terinternalisasi dengan baik terhadap semua anggota kelompok, sedangkan efektivitas layanan dibuktikan dengan hasil skala perilaku grief yang menunjukan adanya penurunan hasil evaluasi awal dan evaluasi akhir pada skor total perilaku grief. Penurunan 
Jurnal Inspirasi Pendidikan, VOL.9, NO.1, Edisi Januari 2019

Teknik Modeling Dalam Bimbingan Kelompok Untuk Mengatasi Grief Remaja Pasca Kematian Orangtua Lolang Maria Masi ${ }^{\text {a }} 1^{*}$, Christmas Prasetia Ate ${ }^{\text {b, } 2}$ Hal: 25-32

perilaku grief adalah sebesar 33,3 poin atau sama dengan $20,81 \%$. Secara lebih spesifiktingkat perilaku grief siswa yang menjadi anggota kelompok sebelum dan setelah diberi layanan bimbingan kelompok dengan teknik modeling dapat dilihat pada gambar dan tabel berikut :

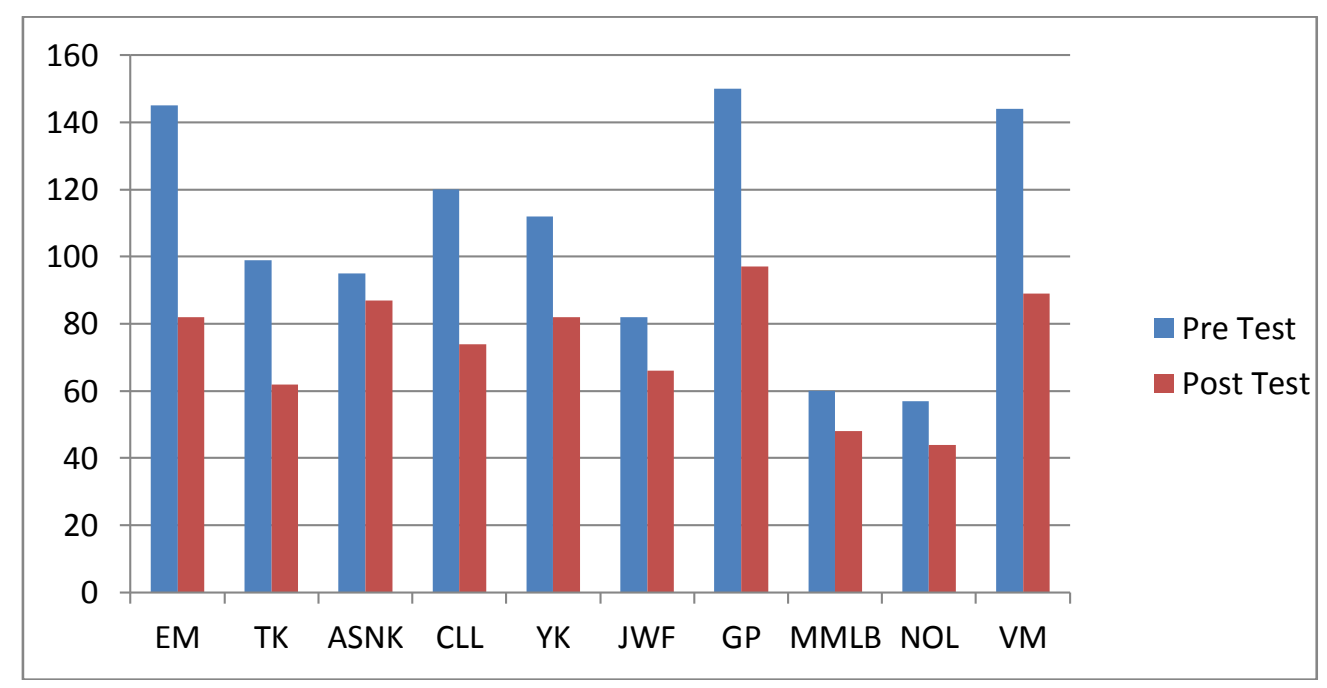

Gambar 1. Perolehan Skor Total Evaluasi Awaldan Evaluasi Akhir Tingkat Perilaku Grief Siswa

Tabel 1.Perolehan Skor Total Evaluasi Awal dan Evaluasi Akhir Tingkat Perilaku Grief Siswa

\begin{tabular}{|c|c|c|c|c|c|c|c|}
\hline & & & & & & & \\
\hline No & $\begin{array}{l}\text { Anggota } \\
\text { Kelompok }\end{array}$ & $\begin{array}{c}\text { Frekuensi } \\
\%\end{array}$ & $\begin{array}{l}\text { Eval. } \\
\text { Awal }\end{array}$ & Kategori & $\begin{array}{l}\text { Eval. } \\
\text { Akhir }\end{array}$ & Kategori & Peng. \\
\hline 1 & EM & $\begin{array}{l}\mathrm{F} \\
\%\end{array}$ & $\begin{array}{c}145 \\
90,63\end{array}$ & $\mathrm{~T}$ & $\begin{array}{c}82 \\
51,25\end{array}$ & K & $\begin{array}{c}63 \\
39,38 \\
\end{array}$ \\
\hline 2 & TK & $\begin{array}{l}\mathrm{F} \\
\%\end{array}$ & $\begin{array}{c}99 \\
61,88\end{array}$ & K & $\begin{array}{c}62 \\
38,75\end{array}$ & $\mathrm{R}$ & $\begin{array}{c}37 \\
23,13\end{array}$ \\
\hline 3 & ASNK & $\begin{array}{l}\mathrm{F} \\
\%\end{array}$ & $\begin{array}{c}95 \\
59,38\end{array}$ & K & $\begin{array}{c}87 \\
54,38\end{array}$ & K & $\begin{array}{l}8 \\
5\end{array}$ \\
\hline 4 & CLL & $\begin{array}{l}\mathrm{F} \\
\%\end{array}$ & $\begin{array}{c}120 \\
75\end{array}$ & $\mathrm{~S}$ & $\begin{array}{c}74 \\
46,25\end{array}$ & K & $\begin{array}{c}46 \\
28,75\end{array}$ \\
\hline 5 & YK & $\begin{array}{l}\mathrm{F} \\
\%\end{array}$ & $\begin{array}{c}112 \\
70 \\
\end{array}$ & $\mathrm{~S}$ & $\begin{array}{c}82 \\
81,25\end{array}$ & K & $\begin{array}{c}30 \\
18,75 \\
\end{array}$ \\
\hline 6 & JWF & $\begin{array}{l}\mathrm{F} \\
\%\end{array}$ & $\begin{array}{c}82 \\
81,25\end{array}$ & K & $\begin{array}{c}66 \\
41,25\end{array}$ & $\mathrm{R}$ & $\begin{array}{l}16 \\
10\end{array}$ \\
\hline 7 & GP & $\begin{array}{l}\mathrm{F} \\
\%\end{array}$ & $\begin{array}{c}150 \\
93,75\end{array}$ & $\mathrm{~T}$ & $\begin{array}{c}97 \\
60,63\end{array}$ & K & $\begin{array}{c}53 \\
33,13\end{array}$ \\
\hline 8 & MMLB & $\begin{array}{l}\mathrm{F} \\
\%\end{array}$ & $\begin{array}{c}60 \\
37,5\end{array}$ & $\mathrm{R}$ & $\begin{array}{l}48 \\
30\end{array}$ & $\mathrm{R}$ & $\begin{array}{l}12 \\
7,5\end{array}$ \\
\hline 9 & NOL & $\begin{array}{l}\mathrm{F} \\
\%\end{array}$ & $\begin{array}{c}57 \\
35,63\end{array}$ & $\mathrm{R}$ & $\begin{array}{c}44 \\
27,5\end{array}$ & $\mathrm{R}$ & $\begin{array}{c}13 \\
8,13\end{array}$ \\
\hline 10 & VM & $\begin{array}{l}\mathrm{F} \\
\%\end{array}$ & $\begin{array}{c}144 \\
90\end{array}$ & $\mathrm{~T}$ & $\begin{array}{c}89 \\
55,63\end{array}$ & K & $\begin{array}{c}55 \\
34,38 \\
\end{array}$ \\
\hline \multicolumn{3}{|c|}{ Rata-rata } & $\begin{array}{c}106,4 \\
66,5\end{array}$ & $\mathbf{S}$ & $\begin{array}{c}73,1 \\
45,69\end{array}$ & $\mathbf{K}$ & $\begin{array}{c}33,3 \\
20,81\end{array}$ \\
\hline
\end{tabular}


Jurnal Inspirasi Pendidikan, VOL.9, NO.1, Edisi Januari 2019

Teknik Modeling Dalam Bimbingan Kelompok Untuk Mengatasi Grief Remaja Pasca Kematian Orangtua Lolang Maria Masi ${ }^{\text {a, }}{ }^{*}$, Christmas Prasetia Ate ${ }^{\text {b, } 2}$

Hal: $25-32$

Tabel 1 menunjukkan perilaku grief semua siswa yang menjadi anggota kelompok mengalami penurunan (nilai evaluasi akhir lebih rendah dari nilai evaluasi awal). Ketercapaian hasil tersebut karena layanan bimbingan kelompok dengan teknik modeling dilaksanakan secara profesional sesuai dengan prosedur yang telah direncanakan, walaupun terjadi beberapa hambatan saat kegiatan berlangsung. Faktor-faktor yang mendukung pengurangan perilaku grief siswa antara lain:

1. Konselor sebagai motivator mampu mengoptimalkan nilai-nilai positif model, tidak hanya pada diri sendiri tetapi juga pada anggota kelompok dalam setiap tahapan layanan bimbingan kelompok. Artinya nilai-nilai dari model terintegrasi secara optimal pada setiap tahapan layanan.

2. Materi yang menjadi topik bahasan, yakni tentang nilai-nilai dari model sesuai dengan tingkat kebutuhan siswa pada umumnya dan anggota kelompok pada khususnya.

3. Konselor sebagai perencana kegiatan mampu memberikan perlakuan yang tepat sesuai dengan topik bahasan dan karakteristik siswa yang menjadi anggota kelompok, yakni usia remaja. Perlakuan yang diberikan tersebut dapat menstimulus anggota kelompok untuk mengoptimalkan kemampuannya sehingga mereka secara aktif menunjukan peranannya dalam menciptakan dinamika kelompok.

4. Konselor mampu memanfaatkan berbagai sarana dan prasarana yang ada di SMA Negeri 3 Kota Kupang untuk mendukung kelancaran pelaksanaan kegiatan (menggunakan LCD)

5. Anggota kelompok mau dan mampu bersikap terbuka serta aktif, tidak hanya saat pelaksanaan layanan bimbingan kelompok dengan teknik modeling, akan tetapi diluar kegiatan tersebut mereka juga menempatkan waktu untuk belajar lebih dalam mengenai topik bahasan.

6. Pembentukan kelompok secara heterogen mampu menumbuhkan dinamika kelompok dengan baik sehingga secara otomatis mampu menstimulus anggota kelompok yang awalnya pasif untuk lebih berperan aktif dalam kegiatan kelompok.

Paparan diatas memberikan gambaran jika pengurangan perilaku grief siswa tidak hanya terjadi pada saat pelaksanaan layanan bimbingan kelompok dengan teknik modeling yang diungkap melalui laiseg dan skala perilaku agresif. Namun demikian, pengurangan tersebut juga tampak dari sikap dan perilaku yang ditampilkan anggota kelompok dalam kesehariannya yang sudah "diwarnai" oleh nilai-nilai positif model. Uji keefektifan model layanan bimbingan kelompok dengan teknik modeling untuk mengurangi perilaku grief siswa SMA dianalisis dengan statistik non-parametrik melalui uji wilcoxon. Hasil uji Evektivitas model yang dikembangkan pada perolehan skor total perilaku grief dapat dilihat pada Tabel 2.

Tabel 2. Uji Wilcoxon Evaluasi Awal dan Evaluasi Akhir Tingkat Perilaku Grief Siswa

\begin{tabular}{|c|c|c|c|c|c|c|c|}
\hline \multirow{2}{*}{ No } & \multirow{2}{*}{ AK } & $\begin{array}{c}\text { Eval.Awal } \\
\text { X1 }\end{array}$ & $\begin{array}{c}\text { Eval.Akhir } \\
\text { X2 }\end{array}$ & $\begin{array}{c}\text { Selisih } \\
\text { (X1-X2) }\end{array}$ & \multirow{2}{*}{ Jenjang } & \multicolumn{2}{c|}{ Tanda Jenjang } \\
\hline 1 & EM & 145 & 82 & 63 & 10 & 10 & - \\
\hline 2 & TK & 99 & 62 & 37 & 6 & 6 & 0 \\
\hline 3 & ASNK & 95 & 87 & 8 & 1 & 1 & 0 \\
\hline 4 & CLL & 120 & 74 & 46 & 7 & 7 & 0 \\
\hline 5 & YK & 112 & 82 & 30 & 5 & 5 & 0 \\
\hline 6 & JWF & 82 & 66 & 16 & 4 & 4 & 0 \\
\hline 7 & GP & 150 & 97 & 53 & 8 & 8 & 0 \\
\hline 8 & MMLB & 60 & 48 & 12 & 2 & 2 & 0 \\
\hline 9 & NOL & 57 & 44 & 13 & 3 & 3 & 0 \\
\hline 10 & VM & 144 & 89 & 55 & 9 & 9 & 0 \\
\hline
\end{tabular}


Jurnal Inspirasi Pendidikan, VOL.9, NO.1, Edisi Januari 2019

Teknik Modeling Dalam Bimbingan Kelompok Untuk Mengatasi Grief Remaja Pasca Kematian Orangtua Lolang Maria Masi ${ }^{\text {a }} 1^{*}$, Christmas Prasetia Ate ${ }^{\text {b, } 2}$

Hal: $25-32$

Hasil penghitungan pada Tabel 2 menunjukkan bahwa uji wilcoxon jumlah jenjang yang terkecil nilainya adalah 0 . Nilai $\mathrm{T}$ tabel dengan $\mathrm{N}=10$ taraf kesalahan 5\% untuk tes 1 fihak (one tail test) nilainya adalah 8 . Ini berarti jumlah jenjang terkecil $=0<$ dari $\mathrm{T}$ tabel $=8$, sehingga Ha diterima dan Ho ditolak. Oleh karena itu, dapat disimpulkan bahwa layanan bimbingan kelompok dengan teknik modeling efektif untuk mengurangi perilaku grief siswa SMA Negeri Sekecamatan Oebobo.

Analisis proses pelaksanaan model yang dikembangkan serta hasil yang dicapai oleh anggota kelompok membuktikan bahwa layanan bimbingan kelompok dengan teknik modeling efektif untuk mengurangi perilaku grief siswa SMA N Sekecamatan Oebobo. Indikasi keberhasilan proses pelaksanaan layanan dapat dilihat dari peran yang dilaksanakan oleh konselor dan anggota kelompok pada setiap tahapan, baik tahapan pembentukan, peralihan, kegiatan, dan pengakhiran dimana pada setiap tahapan tersebut konselor berusaha menanamkan nilai-nilai positif model sehingga terinternalisasi dengan baik terhadap semua anggota kelompok. Sedangkan efektifitas layanan dibuktikan dari hasil skala perilaku grief yang menunjukan adanya penurunan hasil evaluasi awal dan evaluasi akhir pada skor total perilaku grief. Penurunan perilaku grief siswa adalah sebesar 33,3 poin atau sama dengan $20,81 \%$. Selain itu dari hasil uji statistik wilcoxon juga menunjukan jumlah jenjang terkecil $=$ $0 \quad 0<$ dari $\mathrm{T}$ tabel $=8$, sehingga Ha diterima dan Ho ditolak. Maka dapat diberikan makna bahwa model layanan bimbingan kelompok dengan teknik modeling dengan melakukan kegiatan melalui life model dan simbolic modelefektif untuk mengurangi perilaku grief siswa. Semakin baik dalam memberikan layanan bimbingan kelompok dengan teknik modeling akan semakin berkurang perilaku grief siswa, demikian pula sebaliknya semain buruk dalam memberikan layanan bimbingan kelompok dengan teknik modeling tidak maksimal hasilnya dalam mengurangi perilaku grief siswa.

Seperti yang telah dibuktikan secara empiris bahwa model bimbingan kelompok dengan teknik modeling dengan melakukan kegiatan melalui life model dan simbolic modelmerupakan model yang efektif untuk mengurangi perilaku grief siswa. Model yang demikian berarti pemberian layanan bimbingan kelompok dengan teknik modeling yang baik, akan semakin baik pula dalam mengurangi perilaku grief siswa. Hasil penelitian dan pengembangan menunjukan bahwa model bimbingan kelompok dengan teknik modeling dengan melakukan kegiatan melalui permainan dan menghidupkan dinamika kelompok, merupakan model yang efektif untuk mengurangi perilaku grief siswa. Hal ini sesuai dengan pendapat Wibowo (2005:62) bahwa dinamika kelompok adalah suatu studi yang menggambarkan berbagai kekuatan yang menentukan perilaku anggota dan perilaku kelompok yang menyebabkan terjadinya gerak perubahan dalam kelompok untuk mencapai tujuan bersama yang telah ditetapkan.

Senada dengan pernyataan diatas, Prayitno (2012:90) menegaskan bahwa penyelenggaraan layanan bimbingan kelompok yang berkualitas melalui penerapan kegiatan dinamika kelompok yang efektif ditandai dengan hadirnya suasana kejiwaan yang sehat diantara peserta layanan, meningkatnya spontanitas, lahirnya perasaan positif (seperti senang, gembira, rileks, nikmat, puas, bangga), meningkatkan minat atau gairah untuk lebih terlibat dalam proses kegiatan, memungkinkan terjadinya katarsis, serta meningkatnya pengetahuan dan keterampilan sosial. Diperkuat dengan Bandura (1997) bahwa dalam kelompok, siswa belajar melalui observasi dimana tingkahlaku dari seorang individu atau kelompok, sebagai model, berperan sebagai rangsangan bagi pikiran-pikiran, sikap-sikap, atau tingkahlaku sebagai bagian dari individu yang lain yang mengobservasi model yang ditampilkan.

Teknik modeling dalam bimbingan kelompok dapat memberikan nuansa dalam pelaksanaan bimbingan kelompok, karena anggota bimbingan kelompok diajak belajar secara langsung mengenai materi yang diberikan, sehingga anggota kelompok dapat mencari makna 
Jurnal Inspirasi Pendidikan, VOL.9, NO.1, Edisi Januari 2019

Teknik Modeling Dalam Bimbingan Kelompok Untuk Mengatasi Grief Remaja Pasca Kematian Orangtua Lolang Maria Masi ${ }^{\text {a }} 1^{*}$, Christmas Prasetia Ate ${ }^{\text {b, } 2}$

Hal: $25-32$

dari pengalaman intelektual, pengalaman emosional, dan pengalaman fisikal yang diperoleh dari keterlibatan dalam kegiatan bimbingan kelompok dengan teknik modeling. Pengalaman yang diperoleh melalui teknik modeling tersebut dapat dijadikan bekal dalam menyesuaiakan diri bagi kehidupan pribadi maupun dalam hubungan dengan orang lain. Hal ini sependapat dengan Willis (2008:78) yang menyatakan bahwa tujuan utama modeling adalah untuk menghilangkan perilaku tertentu dan membentuk perilaku baru.

Temuan ini mengisyaratkan bahwa siswa yang berperilaku grief jika mau memahami, mengerti dan menyadari nilai-nilai dari modeling maka pada gilirannya yang bersedih karena kehilangan anggota keluarga menjadi bahagia dan tegar. Merasa kehilangan kasih sayang menjadi sadar bahwa masih banyak orang yang mengasihinya, merasa cemas menjadi tenang, merasa bersala menjadi memaafkan diri sendiri, merasa ketakutan akan ditolak menjadi berani menghadapi masa depan, merasa sakit hati dan kesepian menjadi sadar bahwa dirinya tidak sendiri, merasa dikhianati menjadi memaafkan dan menerima keadaan, merasa stres menjadi lebih tenang dan rileks. Tidak aman mejadi tenang dan tenteram, merasa kuatir menjadi berpengharapan, merasa terbeban menjadi legah, merasa depresi menjadi gembira dan senang, merasa sulit berkonsentrasi menjadi lebih berkonsentrasi dan terarah, merasa putus asa menjadi penuh pengharapan, merasa terbayang menjadi lebih fokus ke masa depan, merasa marah menjadi memaafkan dan mengampuni, merasa tidak bermakna dan menutup diri menjadi bermakna dan bermanfaat serta membuka diri terhadap orang lain, merasa ingin bunuh diri menjadi bisa mengontrol diri dan menatap masa depan dengan penuh harapan.

Selanjutnya apabila dikaji dari pelaksanaan bimbingan kelompok dengan teknik modeling dengan kegiatan intinya adalah konselor menyediakan demonstrasi tingkah laku yang menjadi tujuan dengan menggunakan model baik model langsung maupun simolis maka model bimbingan kelompok ini efektif untuk mengurangi perilaku grief siswa, maka hasil empiris ini sesuai dengan teori Bandura (1997) yang menyatakan bahwa tingkah laku motor komplek, pola verbal rumit, dan keterampilan sosial yang halus, juga berbagai reaksi emosional, terhadap stimuli sosial lainnya, dapat dipelajari melalui pengamatan. Sehingga kecakapan-kecakapan sosial tertentu bisa diperoleh dengan mengamati dan mencontoh tingkahlaku model-model yang ada. Reaksi-reaksi emosional yang terganggu yang dimiliki seseorang bisa dihapus dengan cara siswa mengamati orang lain yang mendekati obyekobyek atau situasi-situasi yang ditakuti tanpa mengalami akibat-akibat yang menakutkan dengan tindakan yang dilakukannya.Dengan demikian, dapat dikatakan bahwa hasil penelitian dan pengembangan model bimbingan kelompok dengan teknik modeling untuk mengatasi perilaku grief siswa adalah efektif, artinya ada kesesuaian antara teori dengan data dilapangan.

\section{Simpulan}

Simpulan yang ditarik dalam penelitian ini untuk menjawab hipotesis yang diajukan adalah layanan bimbingan kelompok sudah dilaksanakan di SMA N se Kecamatan Oebobo akan tetapi kegiatan yang dilakukan belum sesuai dengan ketentuan formal pelaksanaan layanan bimbingan kelompok. Rumusan model layanan bimbingan kelompok dengan teknik modeling terdiri dari 8 komponen. Kelayakan model tersebut telah divalidasi oleh 3 pakar bimbingan dan konseling dan 3 pakar praktisi/guru bimbingan dan konseling. Hasil uji kelayakan menunjukan bahwa model yang dirancang layak untuk diimplementasikan dilapangan. Model layanan bimbingan kelompok dengan teknik modeling terbukti efektif untuk mengurangi perilaku grief siswa SMA Negeri Sekecamatan Oebobo. Penerapan layanan bimbingan kelompok dengan teknik modeling, guru bimbingan konseling perlu menjalin kerjasama yang baik dengan guru mata pelajaran dan guru wali kelas agar mendapat dukungan untuk melaksanakan layanan bimbingan kelompok. Guru bimbingan dan konseling 
Jurnal Inspirasi Pendidikan, VOL.9, NO.1, Edisi Januari 2019

Teknik Modeling Dalam Bimbingan Kelompok Untuk Mengatasi Grief Remaja Pasca Kematian Orangtua Lolang Maria Masi ${ }^{\text {a }} 1^{*}$, Christmas Prasetia Ate ${ }^{\text {b, } 2}$

Hal: $25-32$

juga diarapkan dapat melaksanakan model pengembangan ini secara kontinue dengan tetap memperhatikan masukan dari lingkungan/stakeholders yang lain.

\section{Referensi}

Ahsyari, E.R. 2015. Kelelahan Emosional dan Strategi Coping Pada Wanita Single Parent (Studi Kasus Single Parent di Kabupaten Paser). eJournal Psikologi. 3(1)

Alwisol. 2009. Psikologi Kepribadian. Malang: UMM Press

Arikunto, Suharsimi. 2010. Prosedur Penelitian Suatu Pendekatan Praktek. Jakarta: Rineka Cipta

Astuti, Y.D. 2005. Kematian Akibat Bencana dan Pengaruhnya Pada Kondisi Psikologis survivor: Tinjauan Tentang Arti Penting Death Educatioan.

Humanitas: Indonesian Psychological Journal, 1(2), 41-53

Brier, N. 2008. Grief Following Miscarriage: a Comprehensive Review of the Literature. Journal of Woman's Health, 3 (17)

Feist.J. \& J.Gregory. 2008. Teori Kepribadian (Theories of Personality). Jakarta: Salemba Humanika

Fitria, A. \& Deliana, S.M. 2013. Grief Pada Remaja Akibat Kematian Orangtua Secara Mendadak. Developmental and Clinical Psychology, 2(2)

Gibson, R.L. \& Mitchell. 2011. Bimbingan dan Konseling. Yogyakarta: Pustaka Pelajar

Hutomono, S. 2011. Observasional Learning: Metode Psikologis yang Dilupakan dalam Psikologis Olahraga. Jurnal Ilmiah SPIRIT. 11, (2),25-35

Juntika, N. Achmad. 2009. Bimbingan dan Konseling Dalam Berbagai Latar Kehidupan. Bandung: Refika Aditama

Lund, D. \& Vries, B. D. 2010. Experience and Early Coping of Bereaved Spouses/Partners in an Intervention based on the Dual Process Model (DPM).

OMEGA Journal of Death and Dying, 61(6)

Papalia, D.E, Olds, S.W. \& Feldman. 2008. Psikologi Perkembangan (Human Development). Jakarta: Kencana

Prayitno.2012. Jenis Layanan dan Kegiatan Pendukung Konseling. Pandang: Program Pendidikan Profesi Konselor Jurusan Bimbingan dan Konseling FIP UNP

Purwanti,D. \& Ropi, H. \& Widianti, E. 2013. Gambaran Respon Berduka Pada Anak Remaja dengan Orangtua Bercerai di SMP 1 Jatinangor Kabupaten Sumedang.

Jurnal Keperawatan Jiwa, 1(2)

Santrock, J.W. 2008. Perkembangan Anak. Jilid 1. Erlangga

Sugiyono. 2012. Metode penelitian pendidikan (Pendekatan Kuantitatif, kualitatif, dan $R \& D)$. Bandung: Alfabeta

Sundari, A.R. \& Herdajani, F. 2013. Dampak Fatherless Terhadap Perkembangan Psikologi Anak, Prosiding Seminar Nasional Parenting: Yogyakarta.

Willis, Sofyan. 2008. Remaja dan Masalahnya. Bandung: Alfabeta

Winnkel, W.S. \& Hastuti, Sri. 2010. Bimbingan dan Konseling di Institusi Pendidikan. Yogyakarta: Media Abadi 